\title{
医療用チューブ入り軟高㨈の識別コード
}

\author{
武田 豊, 鈴木千恵子, 石井ひろみ, 力久忠昭, 金久保好男 \\ 千葉大学医学部附属病院薬凪部*
}

\section{Labeling of Drug Code on Ethical Ointments in Tube}

\author{
YUtAKa TAKeda, Chieko SUZUKI, HiROMi ISHII, TAdAAKI RIKIHISA, \\ YOSHIO KANAKUBO \\ Hospital Pharmacy, School of Medicine, Chiba University*
}

(Received June 15, 1984)

Trend of the labeling of the drug code on ethical ointments in tube (including creams and jellies) was investigated by means of questionnaires. Drug codes were indicated at $37.5 \%$ of 456 preparations surveyed. While $69.9 \%$ of the companies selling or manufacturing ointment products did not put the drug code on any of their preparations, $15.1 \%$ of the companies labeled the drug code on all of their products. The larger the number of products per company became, the higher the rate of preparations wearing the drug code was. Drug codes were printed on labels in $65.9 \%$ of the preparations, and on the tube in $32.9 \%$. More than $37 \%$ of the companies surveyed had no plan to use the drug code for their ointment products.

It is generally recognized that the drug code is useful to identify such preparations as tablets and capsules. Therefore, wider labeling of the code on ointments is desired.

Keywords_-drug code; drug code for ointments; ethical ointments in tube; trend of drug code labeling; questionnaire; identification of ointments

医薬品製剂の識別コードは, わが国では若干の製薬会 社の自主的な動きと薬剤師からの提案1)を契機に，約10 年前から錠剤とカプセル剂に対して刻印または印刷され るようになり，今日では錠・カプセル剂の鑑定識別にあ たっては不可欠なほぞにまで普及している，また，錠・ カプセル剂のほかに, 分包された散剤や顆粒剂, 軟高 剤，坐剂などに対しても，その一次包装に識別コードが 付されるようになってきている。しかし，識別コードは 製薬会社の自主的判断に委ねられたものであることもあ って, 錠・カプセル剂以外の製剂ではその普及の程度が 明らかでない。

今回著者らは, 医療用のチューブ入り軟膏剤では, 識 別コードがどの程度利用し得るものかを知るために，ア ンケート等により現状を調査したので, その結果を報告 する・

* 千葉市亥鼻 1 丁目 8-1；8-1, Inohana 1-chome， Chiba-shi, 280 Japan

\section{方法}

\section{1. 調查対象品目の遭定}

本調查では，一般にクリームあるいはゼリーと称され ている製剤も軟䘱剤として扱うことにした．調査対象は 1983年11月の時点で薬価基準の外用薬に収載されている チューブ入りの軟亭剂とした.したがって眼科用薬は含 まれるが歯科用薬は含まれない，局方品は除外し，また 規格違いは 1 品目に計数して総数 456 品目を選定した。

\section{2. アンケートによる畔查}

調查対象品目を製造あるいは販売している会社に対し てアンケート用紙を郵送して, 識別コードの実施状況と 会社としての対応について調査した．製造と販売が別の 場合はいずれか 1 社に依頼した。

アンケートの内容

1. 扱い製品ごとの識別コード等の表示状況

2. 識別コード等がない場合の理由と今後の措置につ いて

3. 軟育剤に対する識別コード等表示の要望について 


\section{3. 使用した鑑別衰典類}

1. 高杉益充監修: “薬剤識別コード事典,”昭和58年 改訂版, 医薬ジャーナル社, 1983.

2. 名古屋大学医学部附属病院 編 集: “製剂識別便 覧,"第 4 版, 1983.

3. 日本病院薬剤師会編：“医薬品識別コード一覧 '81," 薬事日報社, 1981; “同 '81追補,” 1982 .

4. 日本医薬情報センタ一編：“医療薬 日本医薬品 集,”第 7版, 薬業時報社, 1983.

\section{結果}

\section{1. アンケートの回収と集計值の㭪正}

調查対象の軟膏剤 456 品目を製造あるいは販売してい る会社は93社であった。 そのうち84社(90.3\%)からアン ケートに対する回答が得られた. 品目数では 422 品目で あった．製品ごとの回答内容は鑑別事典類で照合し，一 致しないるのはアンケートの回答を採用した.アンケー トの回答が得られなかった 9 社については, 別途に識別 コードの有無のみを会社に䦓い合わせて集計に用いた.

\section{2. 識別コードの実施状況}

表 1 亿示したように, 昭和58年11月の時点で調査対象 456 品目のうち 171 品目 $(37.5 \%)$ 飞識別コードが付され ていた.

会社数からみた識別コ一ドの実施状況を表 2 亿示し た. 識別コードの表示率は, 当該会社が扱っている製品 のらちで識別コードを付している品目数を総品目数で除 して求めた.93社のうち65社 $(69.9 \%)$ が識別コードを 全く付していないのに対して，14社 (15.1\%) が扱い製 品すべてに識別コードを付していた.
表 1. 薬効別識別コード表示品目数

\begin{tabular}{|c|c|c|}
\hline 薬 効 別 分 類 & $\begin{array}{l}\text { 調查対象 } \\
\text { 品 目 数 }\end{array}$ & $\begin{array}{l}\text { 識別コート } \\
\text { 表示品目数 }\end{array}$ \\
\hline 鎮痛・鎮痒・収斂・消炎剤 & 347 & 152 \\
\hline 眼科用剽 & 29 & 3 \\
\hline 寄生性皮虐疾患用剂 & 22 & 3 \\
\hline 化膿性矦患用剤 & 18 & 4 \\
\hline 口腔用剤 & 6 & 0 \\
\hline 皮虑軟化剈 & 6 & 0 \\
\hline 血液凝固阻止剂 & 6 & 0 \\
\hline 酵素制剂 & 5 & 4 \\
\hline 抗悪性腫瘍㓣 & 5 & 2 \\
\hline 疛疾用剤 & 4 & 1 \\
\hline 局所麻酔㨈 & 1 & 0 \\
\hline 脳下垂体ホルモン剤 & 1 & 0 \\
\hline 泌尿生殖器用剤 & 1 & 1 \\
\hline 外皮用殺菌消毒刘 & 1 & 0 \\
\hline 毛髮用郕 & 1 & 0 \\
\hline その他の外皮用剈 & 3 & 1 \\
\hline 計 & 456 & 171 \\
\hline
\end{tabular}

表 2. 識別コードの実施状況

\begin{tabular}{c|r|r} 
識別コードの表示率 & \multicolumn{1}{|c|}{ 会 社 数 } & \multicolumn{1}{|c}{ 品 目 数 } \\
\hline $0 \%$ & $65(69.9 \%)$ & $229(50.2 \%)$ \\
$1 \sim 49 \%$ & $2(2.2 \%)$ & $27(5.9 \%)$ \\
$50 \sim 99 \%$ & $12(12.9 \%)$ & $133(29.2 \%)$ \\
$100 \%$ & $14(15.1 \%)$ & $67(14.7 \%)$ \\
\hline
\end{tabular}
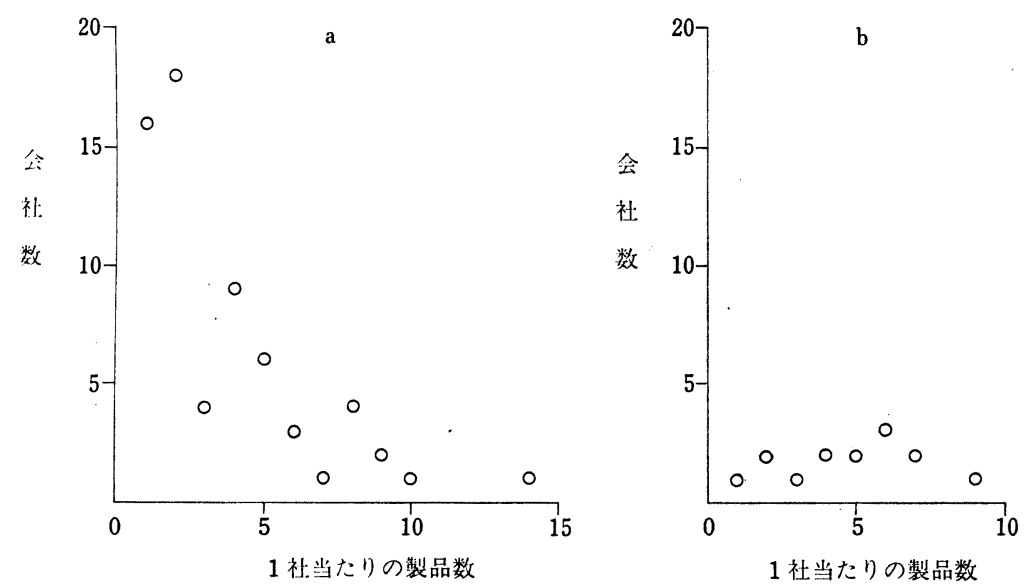

図1. 識別コード表示の有無と会社数の関係

a）全䌘品に識別コードがない場合，b）全䌘品に識別コードがある場合 


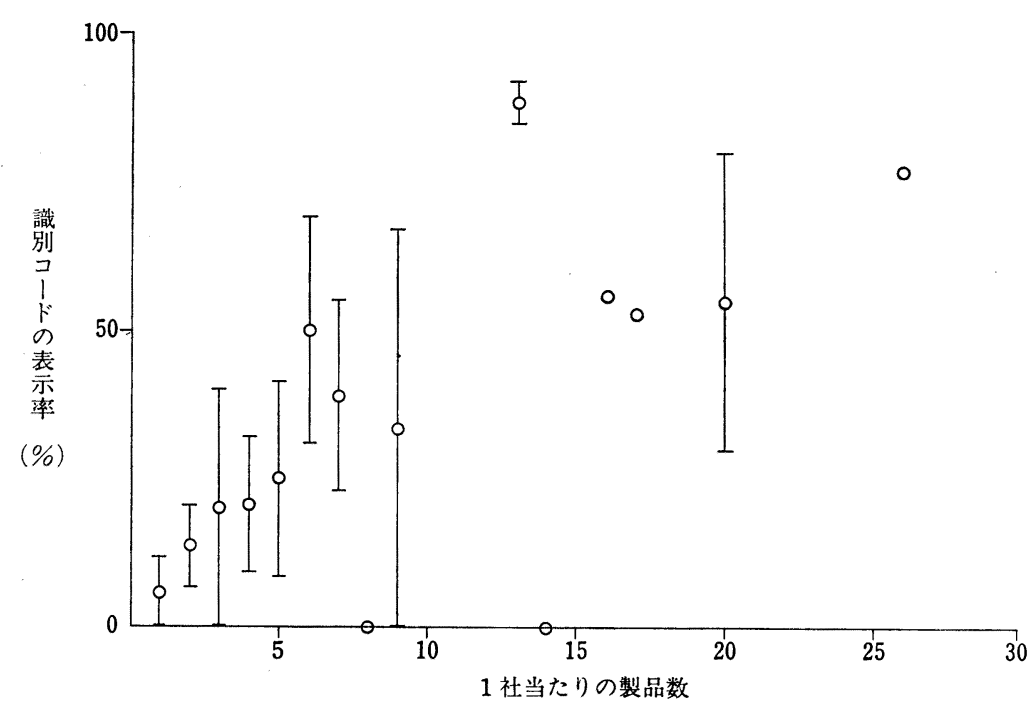

図 2. 1 社当たりの製品数と識別コードの表示率 (平均值士S.E.)

識別コードを全く付していない会社の数と当該会社の 扱い品目数との間には図 $1 \mathrm{a}$ 亿示したように，1社当た りの品目数が少ないほど会社数が多いことが認められた (相関係数-0.773). 一方, 識別コードを全製品に付し ている場合は, 因 $1 \mathrm{~b}$ に示したように，扱い品目数と会 社数には相関が認められなかった。

93社を 1 社当たりの扱い品目数で徉別し，それぞれ識 別コード表示率の平均值を求めると, 四 2 亿示したよう に, 扱い品目数が多くなると表示率が高くなることが認 められた（相関係数 0.351）.

以上のことから，1社当たりの扱い品目数が 1 あるい は 2 品目と少ない場合は, ほとんどの会社が識別コード を付していないが，扱い数が増えるにしたがって識別二 一ドを付す傾向にあることがわかった．

なお，識別コードが付されている171品目のらち，150 品目 $(87.7 \%)$ は使用した 4 種の事典類のいずれかに記 載されていた。

\section{3. 識別コードの表示部分}

識別コードが付されている部分は, アンヶートによれ
ば，65.9\%がラベル，32.9\%がチューブであり，1.2\% は回答が得られなかった.

\section{4. 㳄声剤容器の色と形}

キャップとチューブの色およびキャップの形について アンケートの回答を整理すると表 3 に示したようになっ た. 識別コードの有無に関係なく、キャップとチューブ の色は白と白の組み合わせが約 $40 \%$ で一番多かった。 たキャップの形は直円錐台（表 3, A 形）のものが75 $80 \%$ と圧倒的に多かった.

\section{5. 嫳造あるいは販売会社の識別コードへの対応}

扱い製品中に 1 品目でも識別コードがない場合の理由 と, 今後の措置に関するアンケートに対して以下の結果 を得た。

1. 識別コードのない理由
a) 要望がない
$21.4 \%$
b) 識別可能
$10.0 \%$
c）設備がない
$17.1 \%$
d）必要性を認めない
$12.9 \%$
e) その他
$24.3 \%$

表 3. キャップとチューブの色と形

\begin{tabular}{|c|c|c|c|c|c|c|}
\hline \multicolumn{2}{|c|}{ 色 } & \multicolumn{2}{|c|}{ 割 合 (\%) } & \multirow{2}{*}{ 形 } & \multicolumn{2}{|c|}{ 割 合 $(\%)$} \\
\hline キャップ & チューブ & 全慗 品 & $\begin{array}{l}\text { 識別コード } \\
\text { のない製品 }\end{array}$ & & 全 製 品 & $\begin{array}{l}\text { 識別コード } \\
\text { のない弊品 }\end{array}$ \\
\hline 白 & 白 & 36.0 & 42.1 & A $\square$ & 79.2 & 75.0 \\
\hline 白 & メタル & 8.9 & 7.1 & B & 10.6 & 16.7 \\
\hline 青 & 白 & 6.0 & 7.1 & $\mathrm{C} \square$ & 9.0 & 6.7 \\
\hline そ & の 他 & 49.1 & 43.7 & $D\{$ & 1.2 & 1.6 \\
\hline
\end{tabular}



f）回答なし
$14.3 \%$

2. 今後の措置
a) 計画中
$8.6 \%$
b) 検討中
$38.6 \%$
c）今後とも表示しない
$37.1 \%$
d) その他
$2.9 \%$
e) 回答なし
$12.9 \%$

6. 識別コード表示の要望について

これまでに会社に対して軟高剂幟別コードを表示し て欲しいという要望がなされたか否かのアンケートに対 して, 以下の結果が得られた.

1. 識別コード表示の要望の有無
a) 有
$17.3 \%$
b ) 無
$76.5 \%$
c）回答なし
$6.2 \%$

2. どこからの要望であったか.
a) 薬剤師
$72.2 \%$
b) 医師
$16.7 \%$
c) 看護婦
$5.6 \%$
d）その他
$5.6 \%$

\section{考察}

わが国で錠剤とカプセル剤に識別コードが付されはじ めたころ，すでに，他の剤形にまで識別コードが付され るようになることが期待されていた.2) 以来10数年を経 た今回の調査で，医療用チューブ入り軟膏剤では品目数 で約 $38 \%$ に識別コードが付されて括り，1社当たりの扱 い品目数が多くなるにしたがって識別コードを付する率 は高くなるが, 約70\%の会社（229品目）は識別コード を全く付していないことがわかった．1品目でも識別コ 一ドを付していない会社のうち $37.1 \%$ の会社（109品目） は今後とも付さないと回答しているので，錠肪やカプセ ル剤ほどの普及は早急には望めないと思われる。
実際，錠剂やカプセル剤の鑑別にくらべれば軟高剤の 鑑別を依頼されることは多くない，しかし，依頼された ときは，今回の調査でみたと括り，チューブやキャップ の色や形では判断し得ないので, 識別できるのは 4 割程 度と考えられる。

識別コードを付さない理由の「その他」の中に「抗ガ ン剤であるから」といら回答があった。しかし, 誤用防 止の点からも作用の強い薬注と識別しやすくすべきでは ないかと考光る. 著者らは, 識別の機会は多くないにし ても軟膏剤の識別コードがもっと普及することを希望す る.

チューブ入り軟膏剤の識別コードで検討すべき点は, その表示場所であろう. 現在はラベルに表示された製品 が多い，ラベル本体に医薬品名といっしょに表示したも のは，ラベルがはがされることがあるのであまり意味が ないよらに思われる。:シン目をつけて切りはなした残 りの部分，いわゆる残余ラベル纪表示してあるるのの方 が望ましい，しかし，いずれ汹せよ，ラベルははがされ たり破れたりする可能性があるので，利用者としてはチ ューブに直接表示して欲しいと思う．そして，折目部分 は見にくいので，できれば本体に表示するよう要望した い.

\section{文嗝}

1）堀岡正義, 中川冨士雄 : 薬剤学, 31 , 別冊附録, 68 (1971); 堀岡正義, 浅田浅, 上野高正, 国田 初男, 中川富士雄, 正井英一; 薬骫学, 32 , 別冊 附録，3 (1972); 堀岡正義, 浅田洸, 岡本保治, 朝長文弥, 中川冨士雄, 正井英一 : 薬剤学, 33, 別冊附録, 8 (1973); 堀岡正義, 浅田洸, 岡本保 治, 朝長文弥, 中川富士雄, 正井英一 : 薬凨学, 34, 別冊附録, 8 (1974).

2）堀岡正義 : 医学のありみ，83，219 (1972). 